\title{
THEORETICAL AND PRACTICAL CONSIDERATIONS REFERRING THE DEADLINES OF COURTS IN INDIVIDUAL WORK IN CONFLICT SETTLEMENT ACCORDING THE LABOUR CODE AND LAW NO. 62/2011 OF THE SOCIAL DIALOGUE
}

\section{Onica-Chipea}

\author{
Lavinia Onica-Chipea \\ Faculty of Law, Department of Law and Administrative Sciences \\ University of Oradea, Oradea, Romania \\ *Correspondence: Lavinia Onica Chipea, University of Oradea, 26 General Magheru St., \\ Oradea, Romania \\ E-mail: laviniachipea@gamil.com
}

\section{Abstract}

The scientific approach aims to analyse a topic of particular interest, both for current doctrine and also for professional practice. The institution of notification deadlines of the court in the matters of the resolution of individual labor dispute is currently governed by the provisions the Labor Code, art.283 para.1 letter a. and by those of art. 211 of Law nr. 62/2011 of the Social Dialogue. A simple analysis of these provisions shows that, unlike the Labor Code, Law of the Social Dialogue refers to the assumptions which are subject to art.268 letter $b$. are not provided the letter $d$, art.268. Thus, the solutions offered by those regulations are different and at the same time contradictory doctrine should aim to formulate hypotheses to solve "real conflict of laws", able to avoid delivery of divergent and contradictory solutions of courts in matters which make the subject of our analysis.

Keywords: time limits for bringing cases to court, Labor Code, Law on Social Dialogue, individual labor disputes.

\section{Introduction}

1. General aspects concerning the deadlines for notification of the courts in settling individual labor disputes

Law 62/2011 of social dialogue ${ }^{1}$ and art.248 of the Labor Code was amended by Law no. $40 / 2011^{2}$ replaced the concepts of conflict of rights and conflicts of interest with the following expressions: collective labor disputes and individual labor disputes as forms of labor disputes.

Individual labor disputes $^{3}$ represents that category of labor disputes aiming to exercise certain rights or obligations arising from individual and collective labor contracts or from collective labor agreements of civil servants as well as from other laws and normative acts. Individual labor conflicts are also considered to be: conflicts related to compensation payments for damages caused by parts through failure or inadequate performance of the obligations established within the individual labor contract or employment relationship; conflicts regarding the nullity of individual labor contracts or of their terms as well as conflicts regarding the cessation of employment relations or of some employment terms.

\footnotetext{
${ }^{1}$ Law no. 62/2011 of the social dialogue published in the Romanian Official Gazette no.322/2011;

${ }^{2}$ Law no. 40/2011 published in the Romanian Official Gazette, part I, 225/31.III.2011;

${ }^{3}$ Art. 1 letter $\mathrm{p}$ from Law no. 62/2011 of the social dialogue;
} 
Labor conflict resolution highlights an important aspect of labor jurisdiction, namely time of referral of the competent courts. The mentioned institution is regulated at this time by the provisions of art.283 of the Labor Code, a non-repealed article by the Law of Social Dialogue and by art.211 of the mentioned legislative act.

\section{Referral deadlines of courts in resolving individual labor conflicts}

Applications aiming to solve conflicts of rights must be made by those whose rights have been violated, by respecting certain legislative deadlines, under the penalty of request rejection by the competent court as being submitted too late ${ }^{4}$.

According to art.268 paragraph 1 of the Labor Code, the requests to solve a labor dispute can be formulated as follows:

a. within 30 calendar days from the date when employer's unilateral decision regarding the conclusion, execution, amendment, suspension or cessation of individual employment contract and disciplinary sanction decision were communicated

b. within 3 years after the emergence of the action right, when the subject of individual labor dispute regards the payment of unpaid wages or rights to employee as well as the property liability of the employee in relation to the employer;

c. on the entire period of the contract, if the invalidity of an individual or collective employment contract or of its clauses is required;

d. within 6 months after the emergence of the action right, in case of non-execution of the collective employment contract or of its clauses;

e. in all other cases within 3 years from the after the emergence of the action right (paragraph 2).

In terms of representation conditions' completion by trade unions at unit level, law does not expressly set a time limit for submitting the application, their representation being established by the court at their request, the decision being appealed ${ }^{5}$. Moreover, Law no. $122 / 1996^{6}$ does not set a deadline within which the notification of the court is made regarding employee unions; the employees decide when to submit documents in order to obtain legal personality.

If the employer's unilateral decision regarding the conclusion, execution, amendment, suspension or termination of individual employment contract is challenged, he or she is obliged to submit the evidence which the measure was taken before the first day of the legal hearing. According to art.1887 of the Civil Code, the period of 30 days starts when the employee was acquainted with the decision of the employer and shall be calculated excluding the first day, but taken into account, however, the day of completion of the term.

In order that this term of 30 days to be fulfilled, the following conditions are necessary: the existence of a unilateral legal act issued by that employer; the employer`s act must determine the modification, suspension or termination of individual or collective labor contract; the employer's act may cover any right of the employee based on the individual or collective labor contract; the employer's act must be communicated based on the forms prescribed by law.

Derogated from the provisions of common law, according to which the absolute nullity may be invoked at any time by action or exception, and the relative nullity may be invoked within 18 months, art.268, paragraph 1, letter d., establishes, without making

\footnotetext{
${ }^{4}$ Athanasiu, Al., Dima, L., Labor Law. University Course, All Beck Publishing House, Bucharest, 2005, p.363;

${ }^{5}$ Art.51 paragraph.2, 3, 4 from Law no. 62/2011;

${ }^{6}$ Law no. 122/1996 published in the Romanian Official Gazette, part a I, no. 262 from 25 October 1996, modified;
} 
distinction between absolute and relative nullity, that this elements can be invoked at any time as long as individual or collective labor contract is being valid ${ }^{7}$.

Regarding the provisions of art.268 paragraph 1 letter $d$. of the Labor Code, there was raised an objection of unconstitutionality motivated by the statement that, unlike civil contracts, labor contracts generate various legal effects even after their cessation. In disputes where the exception of unconstitutionality was arose, the cessation of labor relations is contested based on the fact that the valid period of the individual employment contract expired and it is claimed that the limited period of employment has violated the law, and the effect of this clause has occurred since the date of the cessation of employment legal relationships. It should be noted that this clause regarding the period of the individual labor contract could have been subject of the invalidity observation request during the entire validity period of the contract. The effect of this clause has occurred since the date the employer had observed or disposed the cessation of employment relations, only by recording this fact in the labor card, decision that can be appealed within the period prescribed by art.268 paragraph 1, letter a. of the Labor Code.

To these allegations, the Constitutional Court $^{8}$ established that the challenged legal regulations are based on the principle that allows the request of nullity or annulment of some acts. If an individual or collective labor contract is no longer valid, its terms do not exist also, and the request of nullity has no object. But, it is possible that the legal effects of some contractual provisions could continue to occur after the cessation of contracts. The Constitutional Court concluded that the text itself is not unconstitutional, and in such cases those juridical effects can be challenged in court by way of exception if they are contrary to the rights, freedoms or legitimate interests of the individual. Thus, the right of free access to justice and the right to a fair trial are not restricted.

Regarding art.268 paragraph 2 of the Labor Code, according to which in all other contexts not mentioned at paragraph 1 , the request is addressed to the court within 3 years from the emergence of the right to action, was raised another unconstitutionality exception based on the idea of discrimination between different classes of actions. By Decision no. $342 / 2006^{9}$, the Constitutional Court dismissed from this legal text the exception of unconstitutionality, emphasizing that the 30 days mentioned in art.268 paragraph 1 letters a. and b. shall apply when the labor dispute is linked to the unilateral decision of the employer, including disciplinary sanctions, which involves emergency in solving the conflict concerned. The legal norm that establishes a period of 3 years, in other situations, is not a discriminatory provision, the legislature having the right to decide for the establishment of different terms for the observation of real differences between the nature and the subject of various labor disputes ${ }^{10}$.

The period of 30 days, 6 months and 3 years are prescrition terms and therefore their suspension or interruption in accordance with the Civil Code, Law nr.287/2009 republished can be possible ${ }^{11}$. Under the provisions of art. 2532 of the Civil Code the statute of limitations

\footnotetext{
${ }^{7}$ Ștefãnescu, I., T., Theoretical and Practical Treaty of Labor Law, The Legal Universe Publishing House, Bucharest, 2012, p.905;

${ }^{8}$ The Decision of the Constitutional Court published no. 45/11.01.2007, published in the Romanian Official Gazette no. 92/06.02.2007;

${ }^{9}$ The Decision of the Constitutional Court no. 342/2006, published in the Romanian Official Gazette, part I, from 10.05.2006;

${ }^{10}$ Ticlea, Al., Treaty of Labor Law, The Legal Universe Publishing House, Bucharest, 2007, p.963;

${ }^{11}$ Civil Code, Law n.287/2009, published in the Official Monitor no.511 of 24 July 2009, amended by Law no.71/2011 and no.427 corrected in the Official Monitor from 17 June 2011 and in the Official Monitor no. 489 from 8 July 2011; the mentioned normative act repealed the provision of the Decree no. 167/1958 on the extinctive prescription;
} 
is suspended: on the duration of negotiations in order to amicably solve disputes between parties, if they were held in the last 6 months before the expiry of the limitation period; if the legally entitled in action person should or can, by law or contract, use a certain preliminary procedure, as administrative complaint, seeking reconciliation or others alike, while he or she do not known or did not need to know the outcome of that procedure but not more than 3 months after initiation of the procedure, whether the law or contract did not set another term; if the holder of the right or one who violated it is part of the Romanian armed forces, as long as they are in a state of emergency or war, including people who are in the armed forces for reasons of service required by necessities of war; if the one against which flows or would flow the limitation is prevented by an extreme situation to interrupt acts, as long as this limitation exists, the force majeure not being the suspension cause for the limitation period when it is temporary, unless occurs in the last 6 months before the expiry of the limitation period. Also, the provisions of art. 2537 of the Civil Code governs situations where the prescription is interrupted, namely: by a voluntary act of enforcement or recognition in any other way, of the right whose action is prescribed, made by the person who benefits of the prescription; by submitting a request for judgement or arbitration, by registering the debt, by filing the intervention request within the forced observation started by other creditors or by invoking, by way of exception, the right whose action is prescribing; by establishing as a civil part during the criminal investigation or in front of the court, until the beginning of the legal investigation and if compensation are granted by law from officio, the criminal prosecution interrupts the prescription, even if the constitution as civil party did not take place; by any act by which the person who benefits from the prescription is in default.

Article 211 of Law no. 62/2011 regarding Social Dialogue offers a different but contradictory solution in relation to the before mentioned provisions of the Code, regarding the appealing terms within labor disputes in relation to the subject of the litigation.

Thus, according to the text mentioned above, the requests can be submitted by those whose rights have been violated, as follows:

- unilateral measures taken by the employer on the execution, amendment, suspension or cessation of individual labor contract, including certain commitments of payment, may be appealed within 45 calendar days from the date on which the interested part became aware of the measure taken;

- nullity of an individual employment contract may be requested by the parties during the entire period in which the contract applies;

- compensation payments for the damage caused and restitution of certain amounts of money that have formed the subject of undue payment, may be required within 3 years from the date of damage.

A simple analysis of these norms shows that, unlike the Labor Code provisions, art.211 of the Law on Social Dialogue does not refer anymore to the assumptions of art.268 letters b. and e., and partially are no longer stipulated the assumptions of art. 268 letter d. In essence, according to Law no. 62/2011 disciplinary sanctions, invalidity of collective labor contracts and non-execution of collective labor contracts' clauses cannot be challenged anymore $^{12}$.

The doctrinal opinion that was mentioned before considers the solution offered by art.211 of Law of Social Dialogue as "fundamentally flawed, and its application enter in strong collision with the present Labor Code provisions and after the amendments made by Law.40/2011. "Thus, it is considered that in order to avoid violating the constitutional right to

\footnotetext{
${ }^{12}$ Athanasiu, Al., Theoretical and Practical Aspects of Labor Jurisdiction in Light of Law no.40/2011 and Law no. 62/2011, in Athanasiu, Al. (coord.), Amendmets to the Labor Code and the Social Dialogue Code, The Legal Universe Publishing House, Bucharest, 2011, pp. 194-195;
} 
defense and the international documents to which Romania is party, challenging disciplinary sanctions, including disciplinary dismissal, should apply the provisions of art.268 of the Labor Code. The same reasoning imposes the application of the same dispositions also for the assumptions regarding collective labor contracts, namely observing the invalidity, challenging the non-execution of their terms, because the very provisions of Law no. 62/2011 expressly state that disputes arising from implementation of collective labor contracts are settled by the courts.

Regarding the deadline for notifying the court in relation to such litigation, Law no. 62/2011 has not introduced an express term, so that the provisions of art.268 letter e. of the Labor Code will be valid further which stipulate that claims to solve a labor dispute may be made in terms is 6 months after the emergence of the right to action, in the case of nonexecution of the collective labor contract or of some of its clauses.

We state that the change regarding the employee's possibility to challenge the unilateral measures taken by the employer on the execution, amendment, suspension or cessation of the individual labor contract, by giving up the regulation of a specific term when a unilateral measures on the individual labor contract is challenged, will create difficulties. The reason of this interpretation is based on the expressly manifested legislator's intention to establish a different, difficult or even impossible term starting from which the term of 45 days is valid, the term in which the interested part takes knowledge about the decision, although in practice, the most commonly used method is that of communication by the employer of the unilateral decision.

Moreover, the mentioned doctrinal opinion draws attention to the erroneous classification of those 45 days as a calendar period, "as long as is well known and gained within the legal theory" that the term in question is an extinctive limitation period, within which a right of debt could be reclaimed and the appeal can have the character of annulment action.

It also stated, that the only situation when the real conflict of laws would be removed and the provisions of art.211 letter a. of the Law of Social Dialogue would be applicable, aim at unilateral measures relating to the execution, amendment, suspension of labor contract, including commitments of payment, which, in order to produce legal effects does not require the completion of the communication procedure, or it is not expressly regulated in the Labor Code (see, for example, in case when the employer decides the suspension of the labor contract, the procedure regarding the communication of the decision of suspension is not covered).

The proposed solution, in order to remove the divergent and contradictory future solutions of the courts, is to promote a legal appeal or to repeal the provisions on the same terms contained in one of the legal acts.

The doctrine state also that ${ }^{13}$ the correct determination of notifying terms of the courts regarding the resolution of individual labor disputes involves the relationship between the provisions of the Labor Code and those of Law no. 62/2011 ${ }^{14}$. The sustainable solution is to consider that the common law in this area currently consists of the provisions of art.266-275 of the Labor Code, art.208-216 the Law of Social Dialogue. With that reasoning of time sequence of legal acts, the prevalence of notifying terms of court shall be considered case by case as follows: unchanged terms and situations provided by the Labor Code continue to apply and cause their effects and those newly introduced by the Law of Social Dialogue

\footnotetext{
${ }^{13}$ Gheorghe, M., Considerations Concerning the Deadlines for Notification of the Court in Respect of Individual Labor Disputes, Romanian Journal of Labor Law, no. 5 / 2011, pp.72-73;

${ }^{14}$ Idem, pp. 72-76;
} 
modified in accordance with the Labor Code are being first applied, representing norms adopted later.

Thus, regarding the situation of the coexistence of provisions stipulated in art. 268 paragraph 1 letter a. of the Labor Code and the dispositions of art.211 letter a. of the Law of Social Dialogue, cannot be supported the interpretation according to which in the first situation we find ourselves in the presence of an appeal against an employer's unilateral decision, and in the second one, in the presence of a complaint against a unilateral action of the employer or employee, which was not followed by the issuance of a decision (for example, the employer has taken the measure of employee dismissal, forbids the employee to come to work, but does not issue a decision in this respect). The symmetry principle regarding legal norms requires that the ad validitatem written form of an individual labor contract, established by Law no. 40/2011, should be present also in the case of subsequent documents, namely modification, suspension or cessation, in interdependence with it. Thus, the only possible interpretation remains the one that state that against unilateral measures of execution, modification, suspension or cessation of individual labor contract, the requests may be made within 45 days from the date on which the party concerned became aware of the decision, except the requests for damages payment based on pecuniary liability and for those based on the repayment obligation.

Regarding the requests to solve a lobar dispute whose subject is the employer's unilateral decision to stop the individual labor contract, the same doctrine considers rightly that not mentioning them within art. 211 letter a. of Law of Dialogue Social is "a regrettable omission of the legislature". The solution is that of submitting of these requests within the term of 45 calendar days and not admitting that these litigations are not labor disputes, being in the presence of a civil litigation practice $\mathrm{e}^{15}$.

A new aspect contained in the art. 211 letter a. of Law no. 62/2011 is the possibility of disputing payment agreements within the same term of 45 calendar days. The above mentioned doctrinal ${ }^{16}$ opinion supports that the legal text should be interpreted not as a recognition of the commitment to pay as a new method to recover the prejudice caused by employees, but referring to those situations recognized by special law ${ }^{17}$, when a payment commitment could be assumed, namely as a procedure to recover the damages caused by civil servants, military personnel or military units or third parties.

Different point of view were expressed in the specialized literature regarding the appreciation whether or not the payment commitment aimed also at evaluation and damage assessment, stipulated by art.270 paragraph 3 regulated in the Labor Code. Thus, one opinion $^{18}$ (Gheorghe, 2011) states that the payment commitment cannot support the evaluation assessment, because there are different documents, a bilateral and a unilateral act, issued by the employer to achieve an eventual agreement, thus having different vocation. The second opinion ${ }^{19}$ states that through "the payment commitment" the legislature aimed at "the evaluation and damage assessment" and its recovery "by parts agreement" referred to in art.270 paragraph 3 of the Labor Code, or the legal instrument of damages recovery in the case of civil servants (Article 85 of Law no. 188/1999, etc.).

If the situation regulated by the provisions of art. 211 letter b. of the Law of Social Dialogue, it is outlined the legislator's intention to maintain the period of time in which the nullity of an individual labor contract can be requested in the range in which the contract

\footnotetext{
${ }^{15}$ For details regarding the qualifications of a labor dispute as the one that arises in connection with negotiating individual labor contract, regardless of the existence of a legal relationship born under an individual contract of employment, see Ştefănescu, I., T., op. cit., 2012, p.906;

${ }^{16}$ Gheorghe, M., op. cit, in Romanian Journal of Labor Law, no. 5/2011 p.75;

${ }^{17}$ Special laws for the subject analysed, are: Law no.188/1999 regarding the Status of the Public Officer and the Government Order no. 121/1998 regarding the material responsability of military officers;

${ }^{18}$ Gheorghe, M., op. cit., in Romanian Journal of Labor Law, no. 5/2011, p.76;

${ }^{19}$ T,iclea, Al., Commented Labor Code, $2^{\text {nd }}$, Universe Publishing Law, Bucharest, 2011, p.299;
} 
applies. We believe that the legislature's option is correct, expressed both by the provisions of the Labor Code art.268 paragraph $\mathrm{d}$ and by those of art.211 letter b. of Law of Social Dialogue. The rationality of this interpretation starts from the above mentioned idea that if certain legal effects of some contractual clauses continue to occur even after the cessation of such contracts, exists the possibility of contesting them in court through the method of exception, if they are contrary to the rights, freedoms or legitimate interests of the individual. Furthermore, Labor Code recognizes a party in an individual labor dispute for former employees, for the recovery and fulfillment of rights arising from their employment relationship.

The doctrine has expressed the view that the legislature's option is natural because a legal act cannot be abolished as long as it is valid. Moreover, the provisions of art.142 of the Law of Social Dialogue are invoked, referring to the possibility to request the nullity of a collective labor contract or of certain clauses within, all throughout the existence of that contract.

I also draw attention on the provisions of art. 211 letter c. of Law no. 62/2011, which can be susceptible of consequences difficult to overcome, which sets the starting point of the 3 years term beginning from the date of damage ${ }^{20}$ and not from the date when the right to action occurred, given the fact that the mere production of the prejudice is not likely to mark the beginning of the term, requiring more cumulative requirements that are subsumed under the concept of right to action. The legal qualification of the 3 years term, as a prescription and not as a decline term (only in the event of a decline term, the damage could trigger the term), requires the solution regarding the emergence of the right of action and not of the one marking the damage ${ }^{21}$.

The doctrine ${ }^{22}$ has also expressed the view according to which, by setting the prescription term as being that of the flow of the damage, a single legal regime between employees (formerly art.268 letter c. of the Labor Code in conjunction with art. 8 paragraph 1 from the Decree no.167/1958 stipulated the term for the emergence of right at action) and civil servants (in this situation, the term was stipulated at the time of damage) has been created (Gheorghe, 2011), which up to this change had no objective grounds to be set up differently.

Another opinion $^{23}$ supports the view that it is both logical and legal the application of art. 211 letter c. of Law. 62/2011, starting from both the objective character of time covered by the text and the fact that the regulation is more favorable to employees.

The violation of legal terms generates the rejection of the request by the competent court, as being filed too late, and the reinstatement within the time limit can occur if the violation of the term was the result of objective circumstances. The doctrine states that proper grounds for reinstatement within term limit are represented by those situations which, without representing extreme cases, are outside the will and the field of activity of the interestes part, and by their intensity, prevents the part from exercising the right of appeal within the legal time: prolongued hospitalisation, the execution of a custodial sentence, incapability to move, etc. $^{24}$. Also it is considered that invoking reason such as: misinterpretations or errors of law,

\footnotetext{
${ }^{20}$ Idem, p.77;

${ }^{21}$ Athanasiu, Al., Theoretical and Practical Aspects of Labor Jurisdiction in Light of Law no.40/2011 and Law no. 62/2011, in Athanasiu, Al. (coord.), Amendmets to the Labor Code and the Social Dialogue Code, The Legal Universe Publishing House, Bucharest, 2011, p. 197;

${ }^{22}$ Gheorghe, M., op. cit., in Romanian Journal of Labor Law, no. 5/2011, p.78;

${ }^{23}$ T,iclea, Al., Differentiation and non-correlation between the provisions of the Labor Code and Law No 62/2011 on Social Dialogue Regarding Labor Jurisdiction, the Romanian Journal of Labor Law, no. 4 / 2011, p. 15;

${ }^{24}$ The doctrine states that proper grounds for reinstatement within term limit are represented by those situations which, without representing extreme cases, are outside the will and the field of activity of the interestes part, and
} 
the absence of the legal counselor due to objective reasons - as hospitalization, does not justify the reisnatlment within the term ${ }^{25}$.

The interested part may request the competent court the reinstatement within the time limit within 30 days of the date on which it knew or ought to know the cessation of reasons justifying the overcome of prescription time and judging the case (art.2522 Civil Code).

\section{Conclusions}

The coexistence of two competing rules regarding the investigated domain, namely the provisions of art.268 of the Labor Code and those of art.211 of the Law no.62/2011 of Social Dialogue, generates a number of inaccuracies in both the interpretation and especially in their practical application, which justifies the need for careful doctrinal analysis that can generate concrete solutions.

We state, according to a doctrinal view which was referred to during the scientific study $^{26}$, that even in terms of courts referral it concerns, after the adoption of the Law of Social Dialogue, real conflict of laws.

The required solution in order to solve the conflict is certainly a new legislative intervention that can give primacy to Labor Code provisions, case in which the provisions of art.211 of the Law on Social Dialogue should be repealed, or to the mentioned provisions repealing or amending them according to the provisions of art.268 of the Code.

Whatever the legislature decision will be, it will certainly have as main effect that prevention of a non-uniform judicial practice generation, with negative effects on social relations.

\section{Bibliography}

Athanasiu, Al. \& Dima, L., 2005, Labor Law. University Course, All Beck Publishing House, Bucharest;

Ștefănescu, I., T., Theoretical and Practical Treaty of Labor Law, The Legal Universe Publishing House, Bucharest, 2012; 2007;

Ticlea, Al., Treaty of Labor Law, The Legal Universe Publishing House, Bucharest,

Ticlea, Al., Commented Labour Code, $2^{\text {nd }}$, Universe Publishing Law, Bucharest, 2011;

Athanasiu, Al., Volonciu, M., Dima, L., Cazan, O., Labor Code. Comment on articles, Volume II, C.H. Beck Publishing House, Bucharest, 2011;

Athanasiu, Al., Theoretical and Practical Aspects of Labor Jurisdiction in Light of Law nr.40/2011 and Law no. 62/2011, in Athanasiu, Al. (coord.), Amendmets to the Labor Code and the Social Dialogue Code, The Legal Universe Publishing House, Bucharest, 2011;

Gheorghe, M., Considerations Concerning the Deadlines for Notification of the Court in Respect of Individual Labor Disputes, The Romanian Journal of Labor Law, no. 5 / 2011, pp. 72-76;

Ticlea, A1., Differentiation and non-correlation between the provisions of the Labor Code and Law No 62/2011 on Social Dialogue Regarding Labor Jurisdiction, The Romanian Journal of Labor Law, no. 4 / 2011, p. 15.

by their intensity, prevents the part from exercising the right of appeal within the legal time: prolongued hospitalisation, the execution of a custodial sentence, incapability to move, etc. For details see Ștefanescu, I., T., op. cit., 2010, p.884; also it is considered that invoking reason such as: misinterpretations or errors of law, the absence of the legal counselor due to objective reasons - as hospitalization, does not justify the reisnatlment within the term; For details see Athanasiu, Al., Volonciu, M., Dima, L., Cazan, O., Labor Code. Comment on Articles, Volume II, C.H. Beck Publishing House, Bucharest, 2011, pp. 421-422;

${ }^{25}$ Ticlea, Al., Tufan, C., Solving Labor Disputes, Lumina Lex Publishing House, Bucharest., 2000, p. 127.

${ }^{26}$ Athanasiu, Al., Theoretical and Practical Aspects of Labor Jurisdiction in Light of Law no.40/2011 and Law no. 62/2011, in Athanasiu, Al. (coord.), Amendmets to the Labor Code and the Social Dialogue Code, The Legal Universe Publishing House, Bucharest, 2011, p. 198; 